\title{
Orkestrasi Buzzer melalui Media Sosial Microblogging dalam Kampanye Penanganan Virus Covid-19
}

\author{
Ariandi Putra ${ }^{1}$, Irwansyah ${ }^{2}$ \\ ${ }^{12}$ Universitas Indonesia \\ Email: ariandiputra1991@gmail.com
}

Diterima : 20 Juni 2020

Disetujui : 15 Juli 2020

Diterbitkan: 30 Agustus 2020

\begin{abstract}
Abstrak
Tahun 2020, dunia dikejutkan dengan pemberitaan virus Covid-19. Efek domino di segala bidang dan merenggut banyak nyawa menjadi sebuah permasalahan serius dan penting untuk diantisipasi. Media sosial microblogging menjadi saluran yang dipilih dalam rangka memberikan pemahaman terhadap masyarakat oleh buzzer. Dalam melakukan kampanye di microblogging Twitter, buzzer yang terlibat saling bertukar pesan dan informasi agar orkestrasi yang dilakukan serentak, seirama, dan tepat sasaran. Dalam penelitian ini, konsep yang dikembangkan yaitu buzzer, microblogging, dan orkestrasi dengan jenis penelitian kualitatif dan menggunakan metode literatur review. Hasil penelitian menunjukkan bahwa buzzer sukses melakukan orkestrasi dilihat dari penyebaran konten dan informasi melalui like, retweet, dan reply dari setiap postingan. Hal ini menunjukkan eksistensi buzzer dalam revolusi industri 4.0 menjadi bagian penting dalam setiap kampanye yang dilakukan.
\end{abstract}

Kata Kunci: Buzzer, Microblogging, Orkestrasi, Twitter, Virus Covid-19

\begin{abstract}
In 2020, the world was shocked by the news of the Covid-19 virus. The domino effect in all fields and the taking of many lives is a serious and important issue to anticipate. Microblogging social media is the channel chosen in order to provide an understanding of the community by buzzers. In conducting campaigns on Twitter microblogging, the buzzers involved exchanged messages and information so that the orchestration was carried out simultaneously, in tune, and right on target. In this study, the concepts developed are buzzer, microblogging, and orchestration with qualitative research types and using the literature review method. The results showed that the successful buzzer orchestrated viewed from the distribution of content and information through likes, retweets, and replies from each post. This shows the existence of buzzers in the 4.0 industrial revolution became an important part in every campaign carried out.
\end{abstract}

Keywords: Buzzer, Microblogging, Orchestration, Twitter, Virus Covid-19 


\section{PENDAHULUAN}

Revolusi Industri 4.0 menjadi sebuah entitas yang menandai era perkembangan teknologi pada abad ke-20. Perkembangan ini juga turut mengubah cara masyarakat dalam berkomunikasi dan memaknai pesan-pesan yang dikonsumsi melalui teknologi dalam era digital. Gaya hidup masyarakat dalam mengkonsumsi berita dan informasi mengalami perubahan dari bentuk analog menjadi bentuk digitalisasi (Meranti \& Irwansyah, 2018). Surat kabar, majalah, dan radio berevolusi kedalam bentuk online dan bisa diakses melalui gadget atau telpon pintar setiap penggunanya. Perubahan dalam bidang teknologi diwarnai dengan munculnya internet dan akselerasinya terhadap media sosial yang pada saat sekarang menjadi sandaran masyarakat dalam berbagi informasi. Platform media sosial seperti Twitter, Facebook, Instagram, Whatsapp, Telegram sangat digemari dan diunduh jutaan kali.

Survei Asosiasi Penyelenggara Jasa Internet Indonesia (APJII) memunculkan fakta 143,26 juta jiwa dari total 262 juta penduduk menggunakan internet dan sebesar 87,13\% digunakan untuk mengakses media sosial (APJII, 2017). Pada tahun 2018, wearesocial.com, merilis data jumlah pengguna media sosial mencapai 3,196 juta dan Indonesia menempati peringkat tiga tertinggi jumlah pengguna media sosial di dunia (Kemp, 2018). Selain itu, $40 \%$ pengguna internet melakukan online untuk mencari informasi terkait program pemerintah (Graham, 2014).

Riset dari perusahaan di Inggris, We are Social bekerjasama dengan Hootsuite menemukan fakta bahwa lebih dari separuh penduduk Indonesia telah menggunakan media sosial. Angka penetrasi yang mencapai 56\% dengan pengguna sebanyak 150 juta di media sosial dari total 268,2 juta penduduk menjadi sebuah fakta yang disampaikan dalam laporan "around the world 2019" oleh perusaahaan tersebut. Riset yang diterbitkan 31 januari 2019 lalu menunjukkan generasi milenial atau generasi $\mathrm{Y}$ dan $\mathrm{Z}$ menjadi pengguna paling banyak di media sosial dan grafiknya naik 20 juta pengguna dibandingkan tahun sebelumnya. (kompas.com). Media sosial bertujuan untuk sosialiasi, bertukar infromasi, berdiskusi, berkomunikasi, dan berpartisipasi dalam bentuk interaksi sosial antar pengguna serta menciptakan dan memindahkan konten. (Safko, 2010)

Data dan fakta yang tergambar diatas menunjukkan bahwa media sosial menjadi pasar yang sangat 'seksi' dalam industri komunikasi. Jejaring dunia maya memungkinkan penyebaran informasi yang beragam dengan tujuan dan motif tertentu. Setiap orang bisa memproduksi kontennya masing-masing. Kondisi ini dimanfaatkan sebagian orang untuk menyebarkan informasi-informasi dengan tujuan tertentu, misalnya untuk promosi produk, membangun citra individu kelompok maupun organisasi, serta melakukan kampanye hitam, propaganda, teror, dan lain sebagainya (Camil et al., 2017; Rohandi, 2016; Wahyuningtyas, 2017; Veil et al., 2015). Perkembangan teknologi membuat penyebaran informasi berlaih fungsi dari analog ke digital. Perubahan ini seiring dengan dibutuhkannya kerja-kerja buzzer sebagai komunikator yang memudahkan feeding informasi dan membuat orkestrasi dalam kampanye terhadap tema-tema tertentu sehingga menarik untuk dibaca oleh banyak khalayak atau pengguna media sosial itu sendiri. Tak jarang viralitas yang terjadi di media sosial yang dilakukan oleh buzzer di pick up oleh media mainstream menjadi sebuah berita.

Kampanye oleh buzzer terhadap isu-isu tertentu di media sosial umumnya banyak dilakukan di platform Twitter. Algoritma Twitter memberikan sebuah keleluasaan bagi 
penggunanya dalam bentuk hestek atau tagar yang bisa menjadi trending topic sehingga kampanye yang dilakukan bisa diukur viralitasnya melalui hasil dari konten-konten kreatif tersebut dari impression dan reach yang didapat. Loisa dan Setyanto (2012) menggambarkan dalam konteks komunikasi hal tersebut berhubungan dengan kegiatan membujuk sejumlah besar khalayak. Menentukan apa yang penting atau tidak melalui pendekatan budaya sebagai bagian dari persuasi untuk mendapatkan efek yang diinginkan.

Sejatinya, Twitter adalah sebuah layanan media sosial yang termasuk ke dalam bentuk microblogging sebagai penyedia alat untuk melakukan komunikasi yang memberikan kebebasan bagi penggunanya untuk menulis status, opini, dan menyebarkannya. Java (2007), microblogging sebagai sebuah fenomena baru dengan menulis update teks kurang dari 200 karakter mengenai kehidupan penggunanya dan mengirimkan pesan kepada teman atau relasi.

Abugaza (2013) menjelaskan bahwa Twitter resmi berdiri maret 2016 oleh Jack Dorsey, Evan Williams, dan Biz Stone. Layanan platform jejaring sosial dan microblog ini membatasi penggunanya hanya bisa membuat 140 karakter dalam setiap satu kali tweet. Pada bulan januari 2013 yang lalu, 500 juta pengguna tercatat terdaftar di Twitter dan 200 juta diantaranya pengguna aktif. Terdapat klasifikasi tweet sesuai dengan topik dan tema tertentu yang bisa dilihat melalui tagar (hestek) dengan awalan simbol '\#' dan simbol '@' sebagai cara untuk mencari pengguna lain di Twitter, membalas tweet seseorang dengan mencari username nya ataupun mengirim DM bersifat pesan pribadi. Fitur seperti retweet (RT), like, dan reply juga tersedia untuk dibagikan ke pengikut pengguna itu sendiri (Abugaza, 2013).

Buzzer awalnya banyak digunakan dalam pemasaran produk tertentu baik secara sukarela maupun dengan bayaran tertentu. Istilah buzzer muncul seiring dengan berkembangnya internet dan media sosial. Di Indonesia kata 'buzzer' sendiri mulai dikenal publik pada 2012 pada saat pilkada DKI Jakarta. Puncaknya, keberadaan buzzer mulai diakui dan mendapatkan tempat tersendiri dalam ruang-ruang kampanye terutama pada saat pilpres 2014. Setelah itu, banyak agency digital yang menawarkan produk dan jasa strategi komunikasi menggunakan buzzer dalam setiap praktik-praktik pemasaran sebuah produk, brand, perusahaan, maupun lembaga pemerintahan. Tak bisa dipungkiri, lembaga negara seperti kementerian juga banyak menggunakan jasa buzzer dalam mengelola informasi publik, menyampaikan kebijakan-kebijakan, meng-counter isu-isu yang berkembang, hingga menyebarkan informasi terkait prestasi dan capaian kerja kementerian tersebut.

Di tahun 2020, gelanggang media sosial terutama Twitter menjadi tempat bagi banyak orang untuk membuat konten, menyebarkan informasi dan membagikan kisahnya kepada pengguna lainnya. Saat Wabah Virus Covid-19 melanda dunia, Twitter menjadi sebuah sarana rujukan bagi setiap orang dalam mendapatkan informasi tak terkecuali di Indonesia. Setelah diumumkan untuk pertama kalinya oleh Presiden Joko Widodo tentang kasus dua orang positif di Indonesia, alur informasi mengenai virus tersebut makin masif diperbincangkan oleh banyak orang. Twitter merupakan salah satu platform yang banyak digunakan sebagai tempat untuk melakukan kampanye tentang Virus Covid-19 tersebut. Hal ini tercermin dalam tingginya perbincangan mengenai Covid-19 yang terangkum dalam hestek atau tagar yang silih berganti berubah setiap harinya. 
Virus Corona atau Covid-19 adalah virus baru dan para ahli masih terus meneliti sejauh mana keganasan dan tingkat penyebarannya. Gejala utamanya adalah demam, batuk, dan sesak napas. Kelompok lansia (lanjut usia) dan orang dengan penyakit menahun (kronis) memiliki risiko lebih tinggi. Menyebar melalui droplet yaitu tetesan air liur yang terbang dari mulut seseorang akibat batuk atau bersin, yang kemudian masuk ke tubuh orang yang berada di dekatnya melalui mulut, hidung dan mata. Informasi seputar virus ini berubah-ubah dan banyak informasi menyesatkan beredar di masyarakat sehingga pemerintah dan relawan bergerak cepat memberikan edukasi seperti yang terhimpun di website https://kawalcovid19.id/ dan https://www.covid19.go.id/. Namun tidak semua masyarakat bisa mengakses website tersebut, tertarik membaca secara teliti sehingga disinilah letak pentingnya kampanye yang dilakukan oleh buzzer dengan menggunakan media sosial Twitter yang lebih digemari banyak kalangan dalam menghimpun informasi.

Penelitian ini bertujuan mengidentifikasi kampanye yang dilakukan oleh buzzer di Twitter dengan menggunakan hestek atau tagar terkait Virus Covid-19. Melihat bentuk orkestrasi yang dilakukan dalam merancang penyebaran informasi di Twitter. Mengetahui proses dan aktifitas kerja seorang buzzer profesional dalam kampanye dan target yang ingin dicapai. Bagaimana konsep buzzer bisa menjadi salah satu strategi komunikasi dan menjadi sebuah industri baru dalam era internet dan industri 4.0.

Penelitian sebelumnya dari Christiany Juditha (2019) dengan judul "Buzzer di Media Sosial Pada Pilkada dan Pemilu Indonesia" menjelaskan mengenai kerja buzzer dalam proses politik, masifnya penyebaran hoaks, black campaign dan efek negatif dari buzzer itu sendiri. Tujuan studi ini adalah untuk mendapatkan gambaran tentang fungsi ganda para buzzer politik melalui media sosial dalam Pilkada dan Pemilu Indonesia baik sebagai merketing maupun produser kampanye gelap (black campaign). Selanjutnya, ada penelitian dari Juliadi (2017) dengan judul "The Construction of Buzzer Identity on Social Media (A Descriptive Study of Buzzer Identity in Twitter)." Penelitian ini fokus membahas konstruksi identitas buzzer di media sosial menggunakan pendekatan deskriptif dan teori interaksi simbolik mengacu pada George Herbert Mead melalui interaksi dan presentasi diri di Twitter sehingga memunculkan tinggi rendahnya respon follower terhadap sebuah akun berdasarkan konsep diri yang ditampilkan semenarik mungkin. Penelitian lain dari Felicia Riris Loisa (2018) dengan judul "Peran Buzzer Politik dalam Aktivitas Kampanye di Media Sosial Twitter" mengacu kepada komunikasi poliitk yang dilakukan oleh buzzer. Subjek nya adalah orang yang bekerja sebagai buzzer baik secara sukarela ataupun dengan imbalan dan objek nya postingan yang dilakukan di Twitter. Penelitian ini menunjukkan bahwa buzzer profesional atau buzzer dengan imbalan tertentu berperan untuk memperluas suatu informasi melalui aktivitas retweet terkait narasi dan hashtag harian hingga dapat dilihat oleh masyarakat dalam bentuk trending topic.

Berdasarkan penjelasan dari tiga penelitian sebelumnya diatas, kebanyakan mengulas kerja buzzer dari segi politik dan marketing dalam kampanye yang dilakukan di media sosial terutama Twitter fokus kepada aktivitas yang berhubungan dengan efek negatif, penyebaran hoaks, dan konstruksi identitas buzzer itu sendiri. Sedangkan kajian ini bersifat lebih kompleks karena mengulas tentang sebuah orkestrasi yang di desain dengan sangat komprehensif. Tujuan dari penelitian ini ingin mengungkap bentuk orkestrasi isu yang 
dilakukan oleh buzzer dalam kampanye penanganan virus covid-19. Selain itu, buzzer dalam kajian ini menjadi komunikator dalam bidang yang jauh berbeda dari penelitian sebelumnya yaitu mengenai isu wabah yang sedang terjadi di seluruh dunia. Virus Covid-19 menjadi bahan yang dinilai cukup berat untuk dikampanyekan oleh buzzer karena menyangkut hajat hidup banyak orang. Orkestrasi yang dilakukan juga sangat kompleks dengan berbagai macam istilah seperti 'social distancing', 'jaga jarak', 'dirumah aja' dengan tujuan menyadarkan masyarakat pentingnya penanganan Virus Covid-19. Alasan tersebut yang membuat kajian ini menjadi lebih menarik dan mempunyai kebaruan dari penelitian sebelumnya sehingga menjadi penting untuk dilakukan.

Buzzer adalah individu, sekelompok orang, ataupun akun yang memiliki kemampuan dalam bentuk orkestrasi sebuah pesan, menyebarkannya hingga menarik perbincangan oleh khalayak ramai, dan mengamplifikasi pesan tersebut hingga terbangunnya percakapan di media sosial dengan tujuan dan motif tertentu (Camil et al., 2017). Turpin (2008) juga menjelaskan bahwa buzzer berasal dari kata 'buzz' yang berarti dengungan, artinya bahwa buzzer dilakukan untuk menciptakan 'noise' akan sebuah informasi di media sosial dengan tujuan menarik perhatian khalayak agar mereka turut membicarakan produk tersebut dan mencobanya.

Dalam era media sosial, pekerjaan buzzer terlihat sangat menjanjikan. Berbagai bentuk kampanye bisa dilakukan dan dijalani secara multi fungsi oleh buzzer-buzzer tersebut. Seorang buzzer bisa melakukan aktivitas kampanye dengan satu akun namun berbeda orkestrasi sesuai dengan waktu dan jam-jam tertentu. Bisa jadi seorang buzzer ikut bermain isu politik di pagi hari, di kala sore, akun tersebut membicarakan tentang film yang lagi booming. Arbie (2013), industri buzzer sangat membutuhkan kreatifitas sebagai jasa yang dijual kepada klien, memiliki minimal 3000 followers, dapat menunjukkan relevansi dari jasa yang diberikan, jumlah pesan yang cenderung naik setiap hari, memiliki interaksi yang tinggi dengan pengguna lainnya, serta bisa membuat konten yang unik. Lebih lanjut, pandangan dari Kotler dan Keller (2012) tentang buzzer adalah sebuah kegiatan pemasaran yang meliputi konsep kebutuhan, keinginan dan tuntutan, target pasar, penawaran dan merek, serta nilai.

Buzzer memiliki jaringan yang luas, pengetahuan yang baik terhadap isu-isu terkini, sangat aktif di media sosial, dan mampu menciptakan konten-konten yang menarik baik berbentuk meme, infografis, maupun video-video kreatif. Diksi-diksi yang dimiliki oleh seorang buzzer biasanya bersifat persuasif, dan mudah dipahami pembaca. Akses informasi yang dimiliki oleh seorang buzzer tak kenal sekat, tak jarang informasi-informasi penting selalu muncul dari seorang buzzer dan memviralkannya di media sosial. Buzzer yang hebat dan mumpuni bisa dilihat dari jumlah reach dan impression yang didapat setiap kali posting di twitter. Retweet, Like, reply seorang buzzer yang berjumlah ratusan menandakan akun yang dimiliki olehnya memiliki banyak penggemar dan selalu dinanti oleh pengguna lainnya. Oleh karena itu, penting seorang buzzer juga memiliki kemampuan agitasi dan propaganda untuk memantik pembicaraan dari banyak orang, memiliki kemampuan jurnalistik dasar, dan bagus dalam hal tulis menulis.

Akun-akun yang dimiliki oleh seorang buzzer terbentuk karena dua hal; akun organik dan akun anonim. Akun organik dengan kata lain akun asli yaitu akun yang mempunyai 
identitas yang jelas, foto profil nya asli foto buzzer tersebut, nama yang tertera di akun juga sama dengan nama sang buzzer. Sebaliknya akun anonim yaitu akun yang identitasnya disamarkan, tidak diketahui siapa pemilik aslinya, foto profil yang ditampilkan biasanya tidak berbentuk foto orang (jika foto orang, biasanya mengambil foto dari google), dan tidak pernah melakukan kopdar dengan sesama pegiat media sosial karena sifatnya yang anonimitas tersebut.

Menjadi seorang buzzer juga memiliki dua motif; sukarela dan komersial. Menurut Camil et al (2017), seseorang secara sukarela menjadi buzzer karena memang menyukai sebuah produk tertentu, memiliki afiliasi politik kepada calon tertentu, atau memiliki keterikatan emosional dengan informasi atau isu tertentu. Sedangkan motif komersial atau ekonomi adalah karena ada keuntungan finansial yang didapatkan dengan menyebarkan pesan atau konten tertentu sesuai permintaan klien atau penyandang dana. Motif komersial inilah yang pada akhirnya memicu terbentuknya industri buzzer. Mereka digerakkan untuk menyebarluaskan konten atau isu tertentu jika ada klien yang bersedia membayar.

Buzzer dalam dunia internet dan media sosial juga mengikuti proses ekonomi pasar yang terlihat dari tren permintaan dan penawaran. Pekerjaan menjadi buzzer juga penuh dengan ketidakpastian, kadang memiliki banyak permintaan setiap bulannya, kadang juga sepi orderan. Camil et al (2017) menjelaskan bahwa ada tiga pelaku utama dalam industri buzzer yaitu agen komunikasi, klien atau pengguna, dan para buzzer itu sendiri. Agen komunikasi dalam industri buzzer bertugas sebagai penghubung antara klien dengan para buzzer yang dikelolanya. Peran sentral agen komunikasi terlihat dari penentuan berapa banyak jumlah akun yang dimiliki olehnya untuk diberdayakan dalam menggalang orkestrasi tertentu terhadap sebuah isu, bernegosiasi dengan klien terhadap besaran tarif yang akan disepakati bersama. Agen ini juga punya tools yang bisa melakukan pemetaan terhadap akun-akun buzzer yang sangat potensial untuk direkut dan diberdayakan. Yang unuik dari pemetaan tersebut adalah setiap akun buzzer punya spesialisasi isu tersendiri. Sebuah akun yang bagus dalam membuat narasi terhadap isu politik belum tentu bagus juga dalam isu Hak Asasi Manusia. Disinilah letak sentral nya tugas seorang agen politik yang bisa menampilkan pemetaan terhadap klien dan bisa memberikan saran untuk klien agar menggunakan akun-akun apa saja untuk isu-isu yang mau di orkestrasi bersama.

Aplikasi seperti "Social Bearing” bisa memantau akun-akun apa saja yang bermain dalam sebuah orkestrasi yang terhimpun di trending topic bisa dilihat dari tagar yang dimainkan. Tagar tersebut bisa dihitung jumlah reach dan impressionnya, akun yang terlibat, berapa banyak follower dari akun-akun yang terlibat, dan jumlah tweet, retweet, dan replynya. Banyak tools yang tersedia baik secara gratis ataupun berbayar membuat kerja seorang agen komunikasi menjadi lebih sedikit mudah. Data yang terhimpun, bisa digunakan kapanpun sesuai dengan kebutuhan klien. Platform seperti Sociobuzz atau Go Viral juga bisa membantu agen dalam mencari para buzzer. Sedangkan sumber anggaran/dana dan permintaan jasa buzzer berasal dari klien, baik yang berasal dari korporasi, individu ataupun kelompok tertentu (Camil et al., 2017).

Microblogging adalah bentuk komunikasi baru yang memberikan fitur bagi pengguna untuk dapat menggambarkan status mereka saat ini dalam posting singkat yang didistribusikan oleh pesan instan, ponsel, email atau web. Twitter dicirikan dengan pesan 
pendek dan merupakan kebalikan dari blog yang biasanya memuat pesan panjang dan kadang sulit menarik orang untuk membacanya. (Java et al. 2007). Murthy (2018), mendefinisikan microblog dengan karakter yang terbatas untuk melihat dan menerima pesan dari pengguna lainnya.

Sementara itu, Conover (2011) menjelaskan Twitter adalah layanan microblogging berbasis internet gratis. Pengguna dapat mengirim pesan pendek maksimal 140 karakter untuk membagikan informasi secara cepat di antara teman-teman, kenalan, dan semua pengguna dari platform ini. Pesan Twitter sering disebut "tweets" dan disisi lain terdapat istilah "hashtag" dalam tweet untuk menghubungkan pesan saat ini dengan beberapa pesan lainnya dalam satu kesatuan ketertarikan yang sama.

Pada dasarnya, orkestrasi merujuk kepada kegiatan yang berkaitan erat dengan penulisan orkestra atau ansambel. Aktivitas ini biasanya sangat familiar dalam pertunjukan musik untuk menciptakan harmoni yang baik dan alunan indah yang enak didengar. Di dunia musik, prakteknya dibagi dalam dua pendekatan yaitu transcription yaitu menjaga orisinalitas dan arrangement dengan melakukan perubahan yang mencolok (significant), diberbagai aspek, tanpa merubah melodi pokoknya. (Karyawanto, 2018).

Bahasa orkestrasi itu kemudian menjadi sebuah entitas tersendiri dalam kampanyekampanye dan juga mitigasi isu. Mirip dengan dunia musik, orkestrasi di media sosial bertujuan untuk membuat alunan narasi menjadi enak dibaca dan memantik minat banyak netizen untuk ikut terlibat dalam ruang tersebut. Pfefferman et al (2013) Orkestrasi biasanya menggunakan berbagai platform dan saluran untuk memusatkan perhatian pada objek yang konsisten dan gigih dalam pesan. Mengacu pada upaya untuk mencapai kesuksesan dengan menemukan dan mengelola kombinasi kreatif untuk nilai; itu adalah kunci untuk melaksanakan manajemen hubungan baik cara lama maupun baru dalam menyelesaikan sesuatu. Dalam dunia kampanye, orkestasi diwujudkan ketika tim berkolaborasi untuk menyatukan data dan pesan dari seorang klien. Setelah semua tersedia secara komprehensif dengan target audiens yang diinginkan, maka orkestrasi tersebut bisa dijalankan dengan tujuan menyampaikan pesan yang relevan sesuai kebutuhan dan keinginan klien di saluran yang tepat, pada waktu terbaik, dan dengan frekuensi yang diinginkan.

\section{METODOLOGI PENELITIAN}

Menggunakan studi pustaka atau metode literatur review untuk menjelaskan konsep buzzer, microblogging, orkestrasi, media sosial dan pemanfaatannya dalam orkestrasi kampanye virus covid-19. Metode literatur review adalah sebuah cara untuk mengidentifikasi konsep, teori, dan penelitian sebelumnya sehingga bisa mempengaruhi topik peneltian yang akan dilakukan (Ridley, 2012). Nakano \& Muniz Jr (2018) menjelaskan bahwa kajian literatur sangat sentral untuk menjelaskan teori, konsep yang akan digunakan dengan batas-batas yang telah ditetapkan untuk memperkuat argumen penelitian pada teks empiris. Melakukan analisis, sintesis, dan meringkas sejumlah literatur terkait, bisa mengembangkan sebuah teori baru, melakukan pengujian hipotesis, mengevaluasi validitas, dan melihat kualitas penelitian untuk mengidentifikasi kelemahan, kontradiksi, dan inkonsistensi dari penelitian yang dilakukan (Xiao dan Watsoon, 2017). Metode yang dipilih ini memungkinkan penulis untuk menjelaskan konsep buzzer secara detail dan akurat sesuai 
dengan referensi yang sudah ada. Mengembangkan fenomena media sosial dalam hal ini khsusunya Twitter dengan melihat tagar trending topic yang dipersiapkan secara matang. Sujarweni (2014) juga menjelaskan bahwa kajian literatur bertujuan untuk membangun konsep yang menjadi dasar studi dalam penelitian.

Neuman (2014) menggambarkan bahwa kajian literatur harus dilakukan secara selektif, komprehensif, kritis dan sesuai alur. Selektif berarti hanya mengambil studi yang paling relevan. Dalam penelitian ini, penulis melakukan screening data di google dan google scholar dengan melakukan kata kunci 'buzzer', 'microblogging', 'orkestrasi' 'media sosial', 'kampanye buzzer', 'buzzer twitter', 'branding buzzer'. Xiao \& Watson (2017) menjelaskan bahwa database elektronik merupakan sumber utama dari koleksi literatur yang diterbitkan. Selanjutnya, penulis juga melakukan selekasi dengan mengambil literatur yang temanya sesuai dengan tema penelitian ini, minimal konsepnya mempunyai relevansi keterkaitan dan membatasi literatur tersebut terbit dalam jangka waktu 25 tahun terakhir agar masih sesuai dengan perkembangan teknologi industri dan revolusi dalam bidang komunikasi. Untuk mendapatkan daftar literatur lengkap pencarian dilakukan mundur untuk mengidentifikasi pekerjaan relevan yang dikutip oleh artikel (Xiao \& Watson, 2017). Proses analisis literatur dilakukan dengan membagi topik kedalam beberapa subtopik untuk memudahkan ekstraksi data, analisis data, hingga pelaporan temuan hasil kajian. Hasil tinjauan dideskripsikan dalam bentuk tinjauan naratif. Tinjauan naratif untuk mengeksplorasi topik-topik yang terkait dengan masalah sehingga memungkinkan penulis untuk menjelaskan tentang buzzer secara lebih komprehensif. (Xiao \& Watson, 2017).

Sumber data diperoleh dari penelitian terdahulu, jurnal yang sudah dipublikasikan, buku terkait, artikel ilmiah, maupun berita di Internet sebagai pendukung data. Melakukan pencarian dan menemukan referensi yang sesuai, mengkaji keterkaitan referensi dengan topik peneltian sehingga bisa memunculkan dasar kuat dalam penelitian ini. Dengan melakukan proses diatas, bisa memperkaya kajian dan memperkuat konsep mengenai buzzer, orkestrasi, microblogging, dan media sosial tersebut. Penjelasan lain tentang kajian literatur digambarkan tentang sebuah kegiatan membaca, mengumpulkan data pustaka, hingga mengelola bahan penelitian. (Zed, 2008)

Teknik pengumpulan data dalam penelitian ini yaitu data primer dan data sekunder. Data primer adalah akun-akun yang terlibat dalam orkestrasi kampanye penanganan Covid19 dan observasi yang dilakukan terhadap akun tersebut. Selain itu, pengumpulan data juga dilakukan terhadap konsep buzzer, orkestrasi, microblogging, media sosial, dan penjelasan mengenai Virus Covid-19. Selain itu, fokus penelitian ini juga dilakukan terhadap orkestrasi oleh buzzer dengan menggunakan teknik participant observe dengan mengumpulkan data dengan cara observasi unggahan atau konten dari akun yang terlibat. Observasi terhadap akun yang terlibat diambil pada bulan mei 2020 dikarenakan pada saat tersebut berkaitan dengan diterapkan Pembatasan Sosial Berskala Besar (PSBB) di beberapa daerah di Indonesia, seperti Jakarta, Jawa Tengah, Jawa timur, Jawa Barat. Selain itu, bulan ini dipilih karena memasuki bulan puasa dan juga lebaran idul fitri, sehingga upaya kampanye sangat gencar dan massif dilakukan di twitter oleh buzzer-buzzer tersebut yang berkaitan dengan Virus Covid-19 baik kampanye jaga jarak, new normal, larangan mudik, dan lain sebagainya. Tagar yang di observasi sebanyak tujuh tagar. Sementara akun buzzer yang 
dilakukan observasi berjumlah tiga akun. Pemilihan tujuh tagar ini dikarenakan untuk menyaring keywords yang merujuk ke "Covid", "Corona", "Virus". Sedangkan pemilihan tiga akun buzzer disebabkan konsistensi dalam mengangkat tagar selama bulan Mei 2020. Observasi dilakukan langsung di twitter akun buzzer yang telah ditentukan dan juga melalui aplikasi social bearing untuk melihat penyebaran isu.

Penelitian ini menggunakan pendekatan kualitatif yang secara deskriptif menghubungkan subjek dan objek penelitian sehingga bisa dikaji secara teoritis, empiris, dan non-empiris. Moleoeng (2000), metode kualitatif deskriptif bertujuan untuk membangun, menjelaskan, dan menggambarkan kategori data yang ada. Langkah tersebut diambil untuk melihat bentuk nyata dari orkestrasi yang dilakukan oleh para buzzer dan capaian yang dihasilkan dari kampanye penanganan virus covid-19 sehingga hasil yang didapat bisa menjadi sebuah rujukan atau referensi untuk penelitian selanjutnya.

\section{HASIL DAN PEMBAHASAN}

Orkestrasi yang dilakukan oleh buzzer di Twitter terlihat sangat masif terutama pada bulan Mei 2020 dimana kebijakan Pembatasan Sosial Berskala Besar atau PSBB yang diterapkan oleh pemerintah di berbagai daerah mulai tarik ulur sesuai dengan kondisi di lapangan. Kampanye jaga jarak melalui aktor-aktor komunikasi baik secara resmi ataupun melalui buzzer memanfaatkan ceruk twitter sebagai tempat dalam sosialisasi gencar dilakukan. Bulan Mei juga menjadi titik balik penting karena bertepatan dengan bulan puasa dan lebaran idul fitri yang untuk pertama kali dilaksanakan di tengah pandemi global. Masyarakat Indonesia yang mayoritas muslim harus bisa beradaptasi dengan virus corona dan menjalankan protokol keamanan sesuai himbaun pemerintah untuk "Beribadah di rumah", Belajar di rumah", dan Bekerja di rumah".

Kampanye tersebut tentu butuh perpanjangan tangan melalui buzzer-buzzer yang memiliki follower besar di Twitter dan juga mempunyai impressi serta jangkauan luas dalam penyebaran informasi. Tagar selama bulan Mei juga disepakati dan dijalankan secara bersama-sama agar menarik perhatian netizen untuk membaca informasi yang diberikan.

Tagar tersebut telah di list sesuai observasi yang dilakukan. Biasanya tagar mulai terlihat di okrestrasi oleh buzzer sepanjang hari dari pagi hingga malam secara berkala. Daftar list tagar seperti yang terlihat dibawah ini:

\begin{tabular}{|c|l|l|}
\hline \multicolumn{3}{|c|}{ Daftar Pantauan Tagar di Media Sosial Twitter Selama Bulan Mei } \\
\hline No & \multicolumn{1}{|c|}{ Hari / Tanggal } & \multicolumn{1}{c|}{ Nama Tagar } \\
\hline 1 & Jumat, 1 Mei 2020 & \#BanpresPeduliRakyat \\
\hline 2 & Sabtu, 2 Mei 2020 & \#AwasProvokasiSaatPandemi \\
\hline 3 & Minggu, 3 Mei 2020 & \#PetaniPahlawanMasaPandemi \\
\hline 4 & Senin, 4 Mei 2020 & \#ImunKuatCovidMinggat \\
\hline 5 & Selasa, 5 Mei 2020 & \#OjoMudikCegahCovid \\
\hline 6 & Rabu, 6 Mei 2020 & \#DukungUUCorona \\
\hline 7 & Kamis, 7 Mei 2020 & \#MudikTetapDilarang \\
\hline 8 & Jumat, 8 Mei 2020 & \#TheNewNormalLife \\
\hline
\end{tabular}




\begin{tabular}{|c|c|c|}
\hline 9 & Sabtu, 9 Mei 2020 & \#OptimisPandemiBerakhir \\
\hline 10 & Minggu, 10 Mei 2020 & \#LawanProvokatorPandemi \\
\hline 11 & Senin, 11 Mei 2020 & \#RakyatWarasPercayaJokowi \\
\hline 12 & Selasa, 12 Mei 2020 & \#AdaptasiDenganCorona \\
\hline 13 & Rabu, 13 Mei 2020 & \#SinergitasHadapiCovid19 \\
\hline 14 & Kamis, 14 Mei 2020 & \#RakyatBersatuCekalCovid19 \\
\hline 15 & Jumat, 15 Mei 2020 & \#StopAkaliMudik \\
\hline 16 & Sabtu, 16 Mei 2020 & \#ProduktifDitengahPandemi \\
\hline 17 & Minggu, 17 Mei 2020 & \#StopPolitikDitengahPandemi \\
\hline 18 & Senin, 18 Mei 2020 & \#DisiplinAturanPSBB \\
\hline 19 & Selasa, 19 Mei 2020 & \#PSBBBelumDilonggarkan \\
\hline 20 & Rabu, 20 Mei 2020 & \#ShalatIdDirumahAja \\
\hline 21 & Kamis, 21 Mei 2020 & \#StopProvokasiDitengahPandemi \\
\hline 22 & Jumat, 22 Mei 2020 & \#StopMudikDisiplinPSBB \\
\hline 23 & Sabtu, 23 Mei 2020 & \#TakbiranDirumahAja \\
\hline 24 & Minggu, 24 Mei 2020 & \#LebaranDirumahCegahCovid19 \\
\hline 25 & Senin, 25 Mei 2020 & \#BersiapMenujuNewNormal \\
\hline 26 & Selasa, 26 Mei 2020 & \#DisiplinKunciNewNormal \\
\hline 27 & Rabu, 27 Mei 2020 & \#NewNormalPulihkanEkonomi \\
\hline 28 & Kamis, 28 Mei 2020 & \#DisiplinProtokolNewNormal \\
\hline 29 & Jumat, 29 Mei 2020 & \#NewNormalCegahPHK \\
\hline 30 & Sabtu, 30 Mei 2020 & \#RakyatDukungNewNormal \\
\hline 31 & Minggu, 31 Mei 2020 & \#SukseskanNewNormal \\
\hline
\end{tabular}

Tabel 1 (Data tagar di Twitter selama bulan Mei 2020)

Tagar diatas, setiap hari dinaikkan oleh aktor-aktor komunikasi atau buzzer di media sosial twitter. Akun yang terlibat dan terus secara konsisten ada dalam setiap isu adalah @DwiyanaDKM, @ChusnulChotimah, dan @jr_kw19. Daftar list dibawah ini akan menjelaskan mengenai ketiga akun tersebut setelah hasil observasi langsung di media sosial twitter.

\begin{tabular}{|l|l|l|l|}
\hline No & \multicolumn{1}{|c|}{ Nama Akun } & Jumlah Followers & \multicolumn{1}{c|}{ Bio Profil } \\
\hline 1 & @dwiyanaDKM & $4,8 \mathrm{~K}$ & $\begin{array}{l}\text { Sometimes you just have to give yourself } \\
\text { the pep talk. Like hello you are a Queen } \\
\text { don't be sad you're doing great love you. } \\
\text { (dwiyana_DKM) }\end{array}$ \\
\hline 2 & @ChusnuIChotimah & $66,3 \mathrm{~K}$ & - \\
\hline 3 & @jr_kw19 & $43,2 \mathrm{~K}$ & Pengelana \\
\hline
\end{tabular}

Tabel 2 (Nama akun buzzer yang terlibat)

Ketiga akun diatas konsisten melakukan kampanye dan terbukti melalui tangkapan layar hasil observasi seperti dibawah ini; 


\section{1. \#OjoMudikCegahCovid}

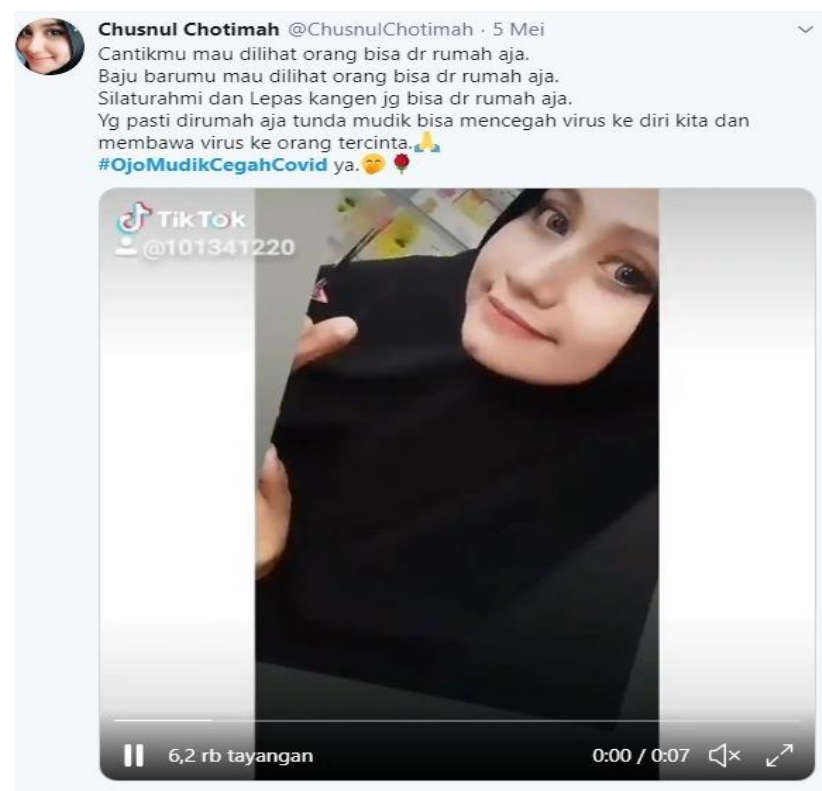

Gambar 1:

Cuitan yang dilakukan oleh akun@Chusnul Chotimah dengan menggunakan tagar \#\#OjoMudikCegahCovid mendapat like sebanyak 321, retweet 66, dan reply 41

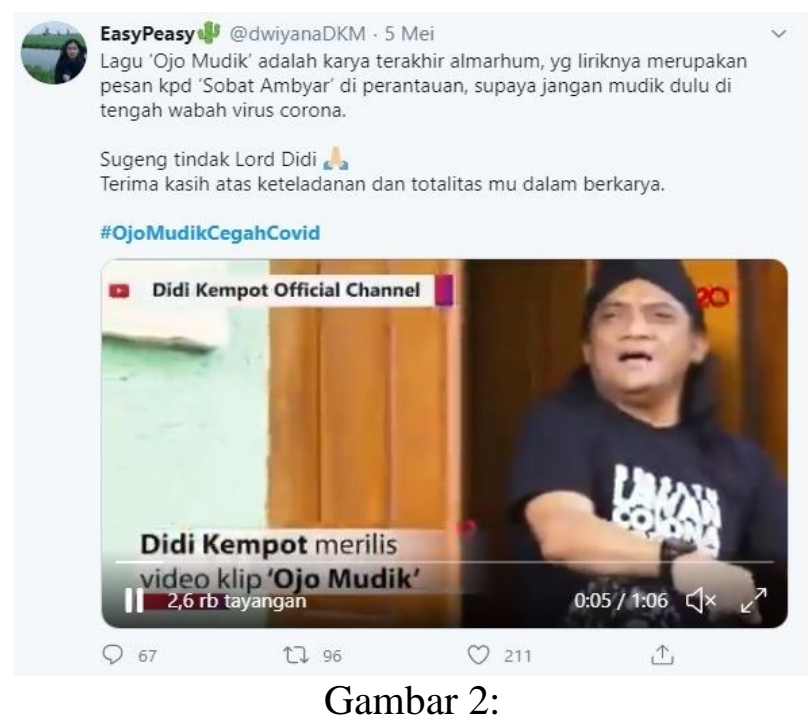

Cuitan yang dilakukan oleh akun @ dwiyanaDKM dengan menggunakan tagar \#\#OjoMudikCegahCovid mendapat like sebanyak 211, retweet 96, dan reply 67 


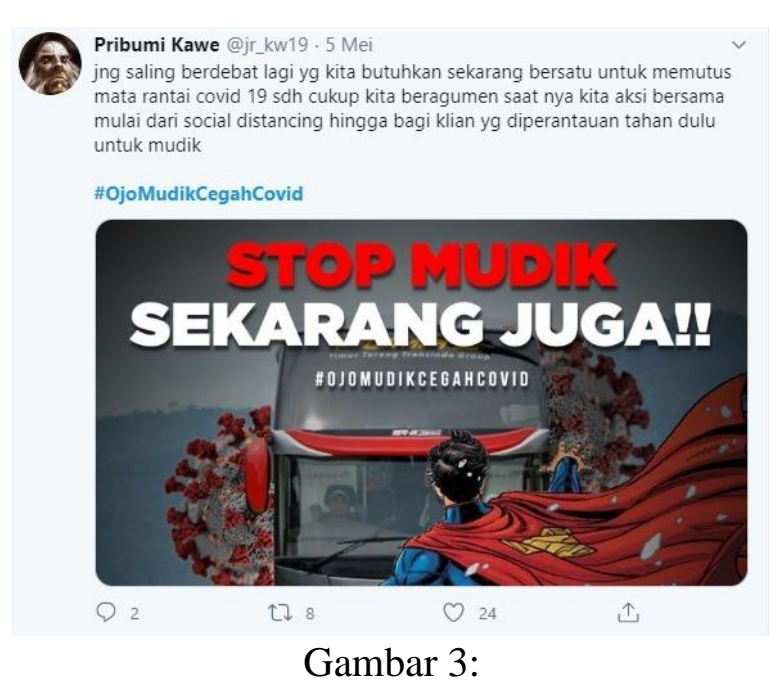

Cuitan yang dilakukan oleh akun @jr_kw19 dengan menggunakan tagar \#OjoMudikCegahCovid mendapat like sebanyak 24, retweet 8, dan reply 2

\section{2. \#DukungUUCorona}

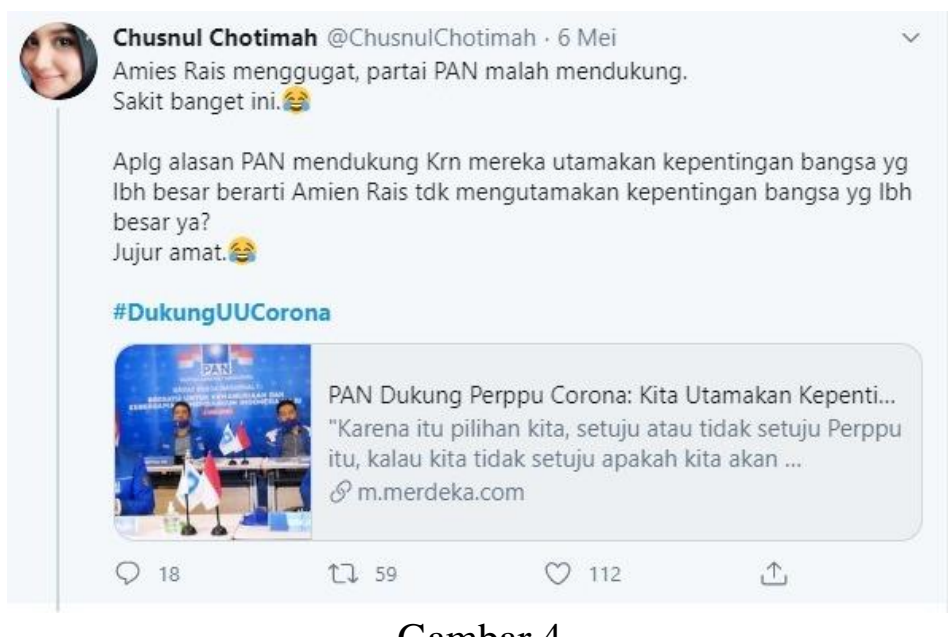

Gambar 4

Cuitan yang dilakukan oleh akun @ChusnulChotimah dengan menggunakan tagar \#DukungUUCorona mendapat like sebanyak 112, retweet 59, dan reply 18 
EasyPeasy \&ी?dwiyanaDKM.6 Mei

Dibutuhkan langkah yg tidak biasa yg harus di ambil Pemerintah dlm menghadapi wabah corona yg dampaknya berimbas pd perekonomian nasional.

DPR mendukung langkah2 strategis tersebut, termasuk mendukung Perppu Pemerintah apabila dibutuhkan revisi APBN.

\#DukungUUCorona

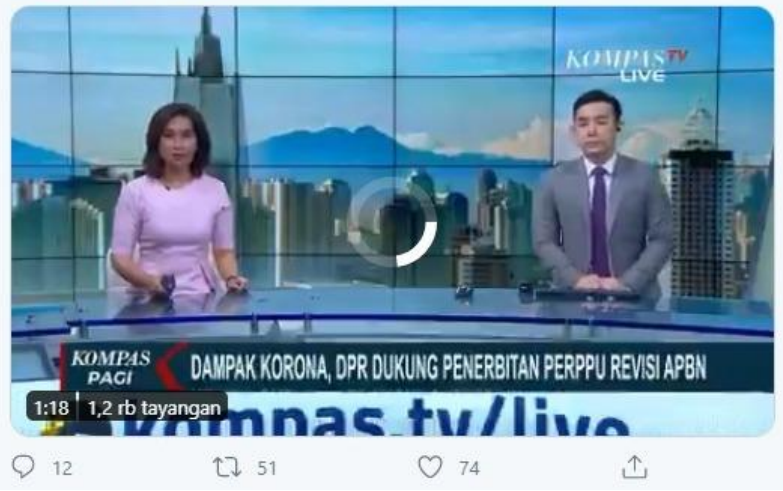

Gambar 5:

Cuitan yang dilakukan oleh akun @ dwiyanaDKM dengan menggunakan tagar \#DukungUUCorona mendapat like sebanyak 74, retweet 51, dan reply 12

Pribumi Kawe@jr_kw19.6 Mei

tujuan Perpu 1/2020 adalah semata2 memberikan ruang gerak bagi pemerintah untuk melakukan stimulus fiskal dan langkah2 lain yang diperlukan

Tidak ada maksud untuk menciptakan impunitas apapun dalam Perpu $1 / 2020$, ujar stafsus Dini

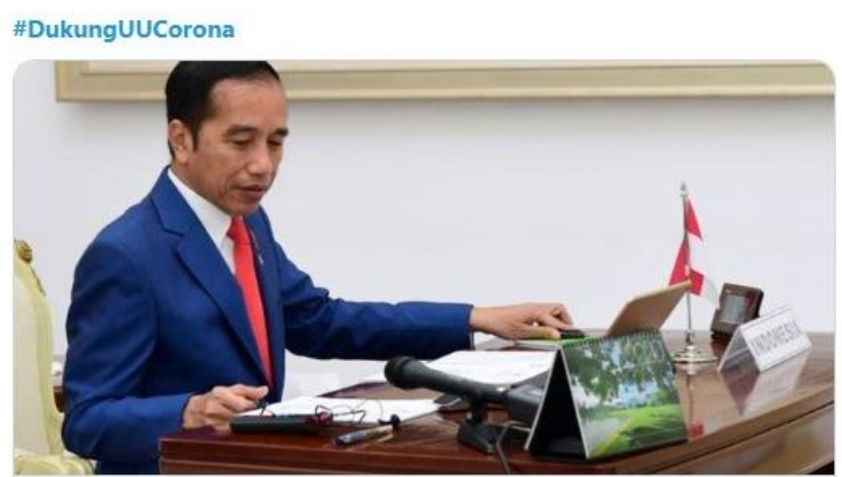

Istana: Perpu Beri Ruang Gerak untuk Beri Stimulus Corona

Fleksibilitas keuangan negara ini dibutuhkan agar keuangan negara

dapat mengantisipasi dampak Corona terhadap perekonomian nasional. S bisnis.tempo.co
Q 6
〔 27
○5 个
Gambar 6:

Cuitan yang dilakukan oleh akun @jr_kw19 dengan menggunakan tagar \#DukungUUCorona mendapat like sebanyak 35, retweet 27, dan reply 6

\section{3. \#AdaptasiDenganCorona}




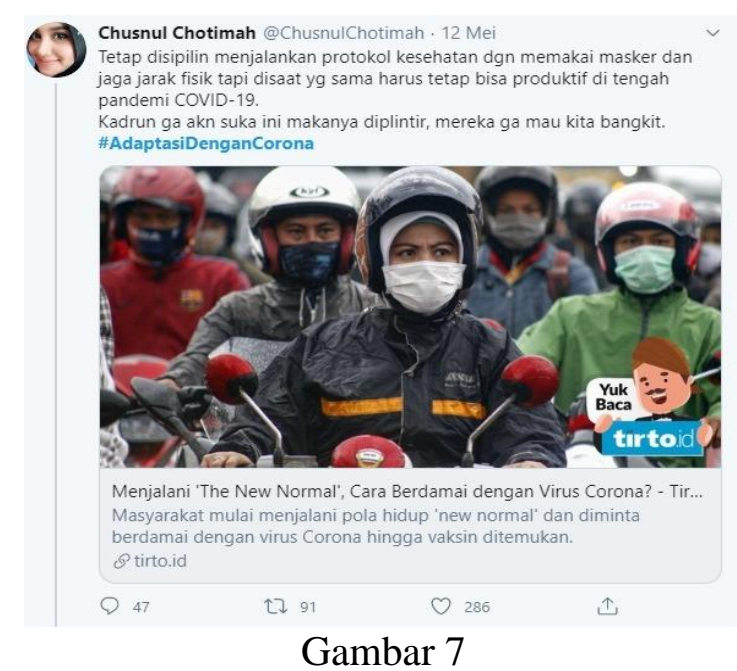

Cuitan yang dilakukan oleh akun @ChusnulChotimah dengan menggunakan tagar \#AdaptasiDenganCorona mendapat like sebanyak 286, retweet 91, dan reply 47

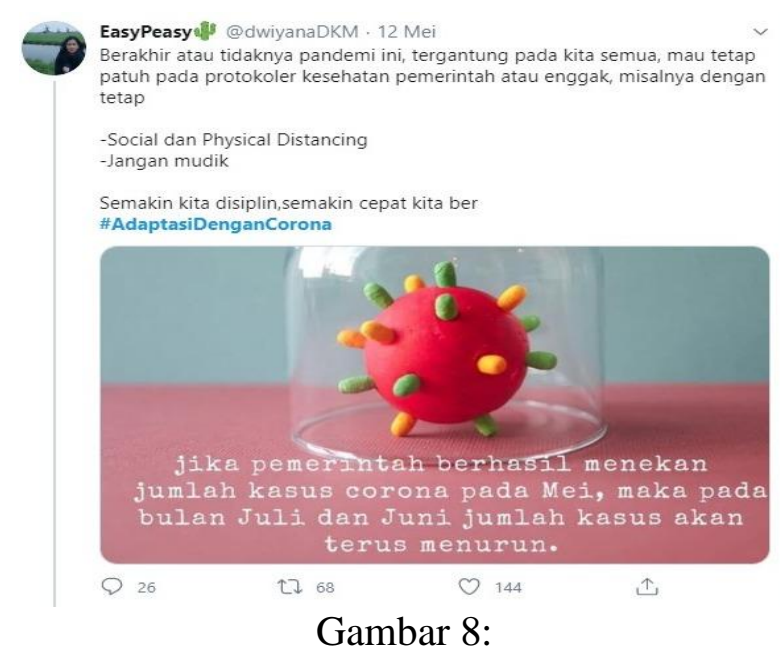

Cuitan yang dilakukan oleh akun @ dwiyanaDKM dengan menggunakan tagar \#AdaptasiDenganCorona mendapat like sebanyak 144, retweet 68, dan reply 26

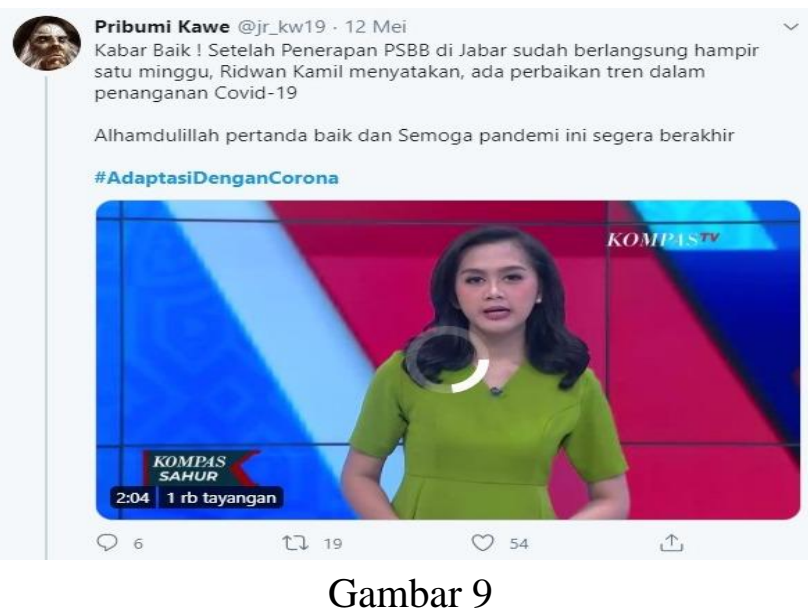

Cuitan yang dilakukan oleh akun @jr_kw19 dengan menggunakan tagar \#AdaptasiDenganCorona mendapat like sebanyak 54, retweet 19, dan reply 6 


\section{4. \#SinergitasHadapiCovid19}

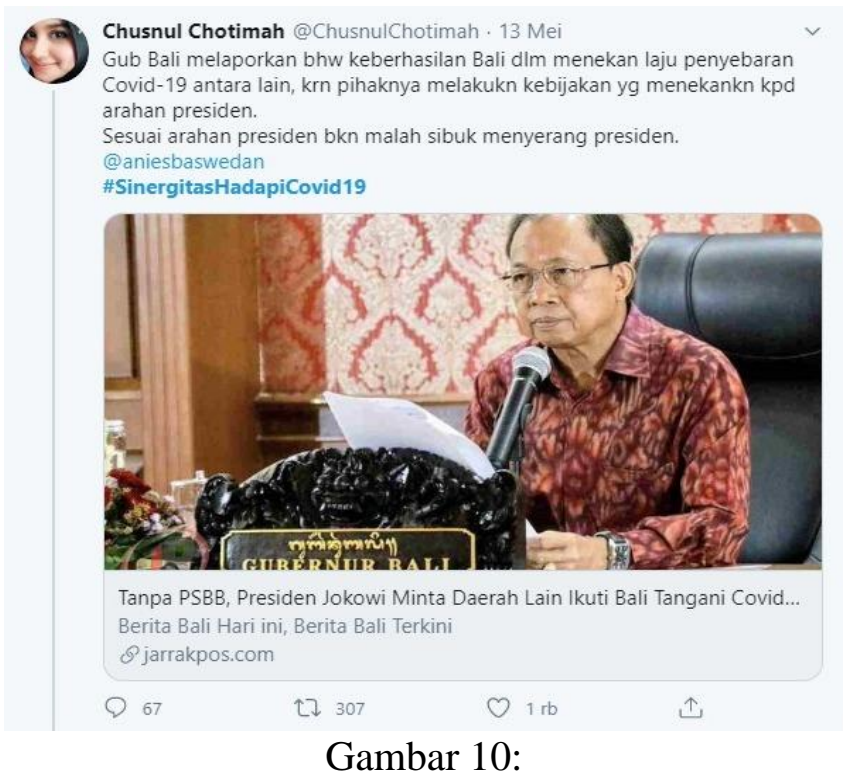

Cuitan yang dilakukan oleh akun @ChusnulChotimah dengan menggunakan tagar \#SinergitasHadapiCovid19 mendapat like sebanyak 1000, retweet 307, dan reply 67

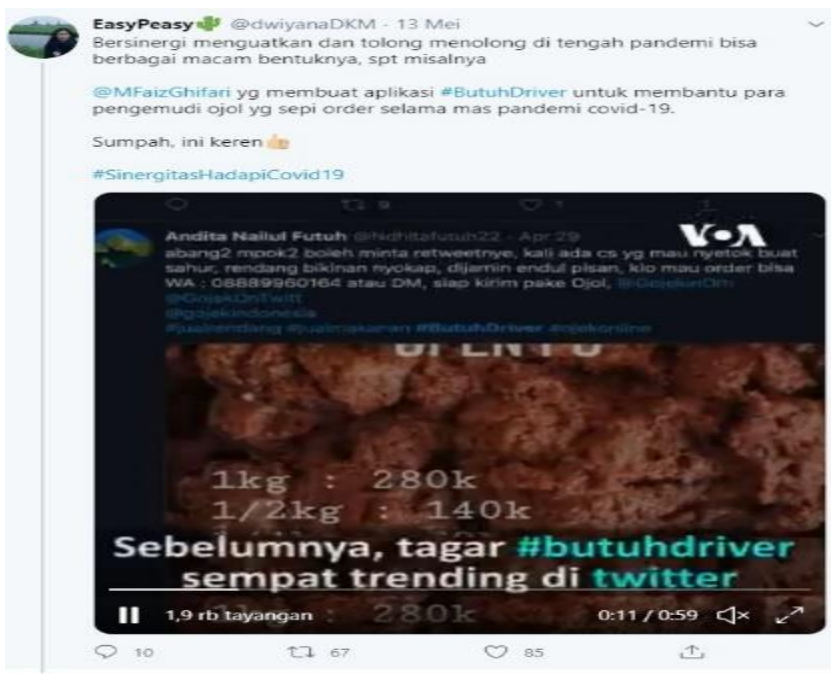

Gambar 11

Cuitan yang dilakukan oleh akun @dwiyanaDKM dengan menggunakan tagar \#SinergitasHadapiCovid19 mendapat like sebanyak 85, retweet 67, dan reply 10 


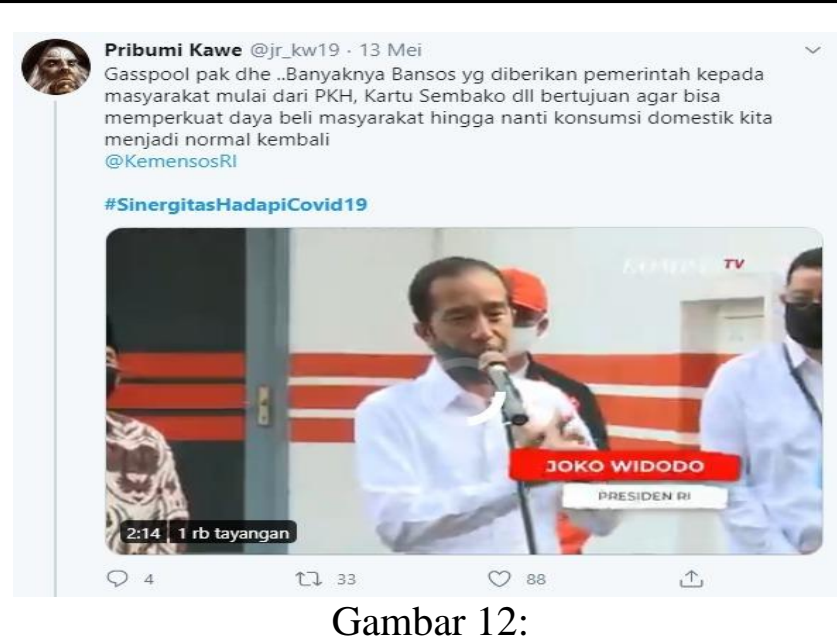

Cuitan yang dilakukan oleh akun @jr_kw19 dengan menggunakan tagar \#SinergitasHadapiCovid19 mendapat like sebanyak 88, retweet 33, dan reply 4

\section{5. \#RakyatBersatuCekalCovid19}

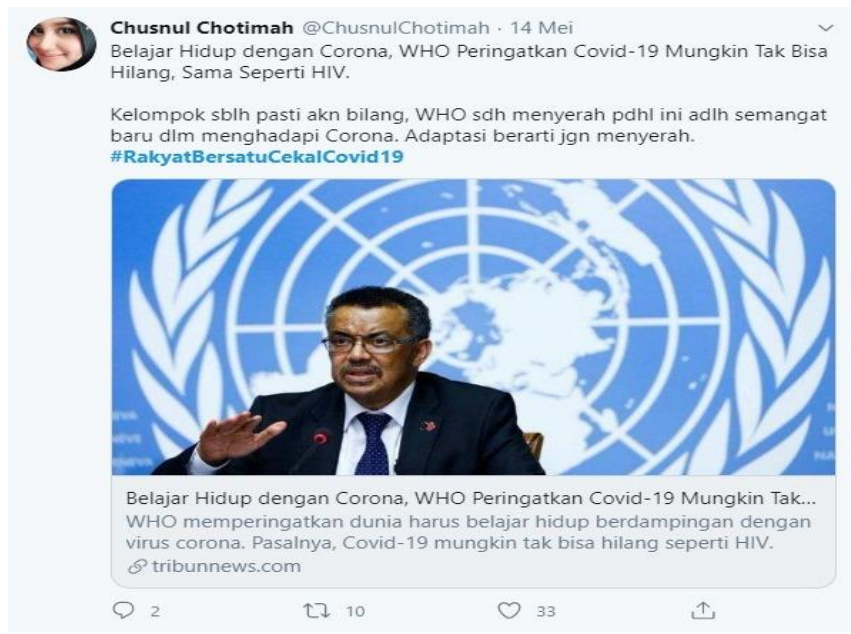

Gambar 13:

Cuitan yang dilakukan oleh akun @ChusnulChotimah dengan menggunakan tagar \#RakyatBersatuCekalCovid19 mendapat like sebanyak 33, retweet 10, dan reply 2

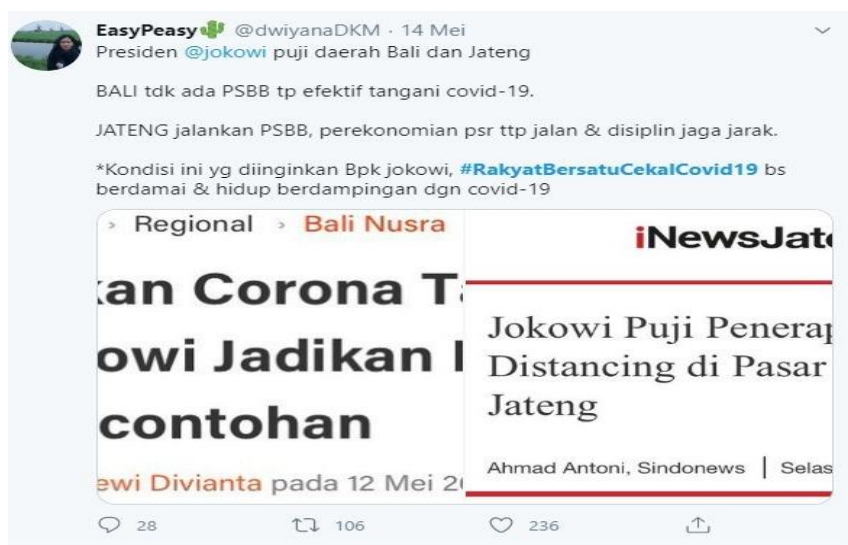

Gambar 14:

Cuitan yang dilakukan oleh akun @dwiyanaDKM dengan menggunakan tagar \#RakyatBersatuCekalCovid19 mendapat like sebanyak 236, retweet 106, dan reply 28 


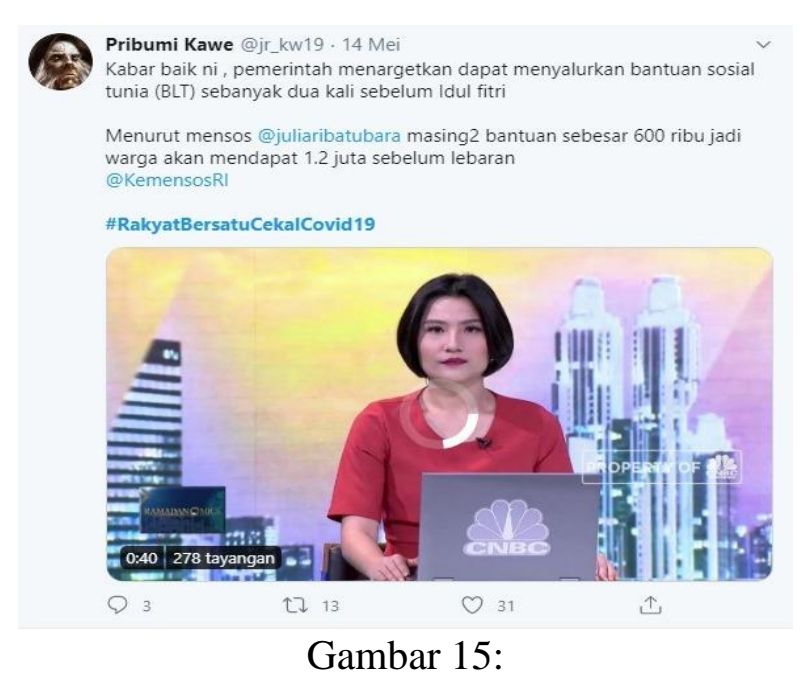

Cuitan yang dilakukan oleh akun @jr_kw19 dengan menggunakan tagar \#RakyatBersatuCekalCovid19 mendapat like sebanyak 31, retweet 13, dan reply 3

\section{6. \#LebaranDirumahCegahCovid19}

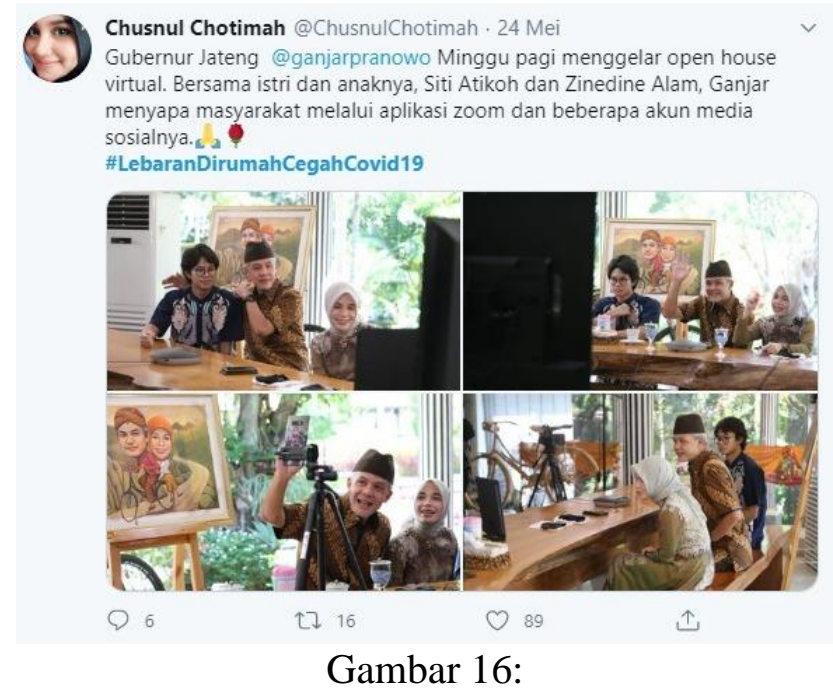

Cuitan yang dilakukan oleh akun @ChusnulChotimah dengan menggunakan tagar \#LebaranDirumahCegahCovid19 mendapat like sebanyak 89, retweet 16, dan reply 6

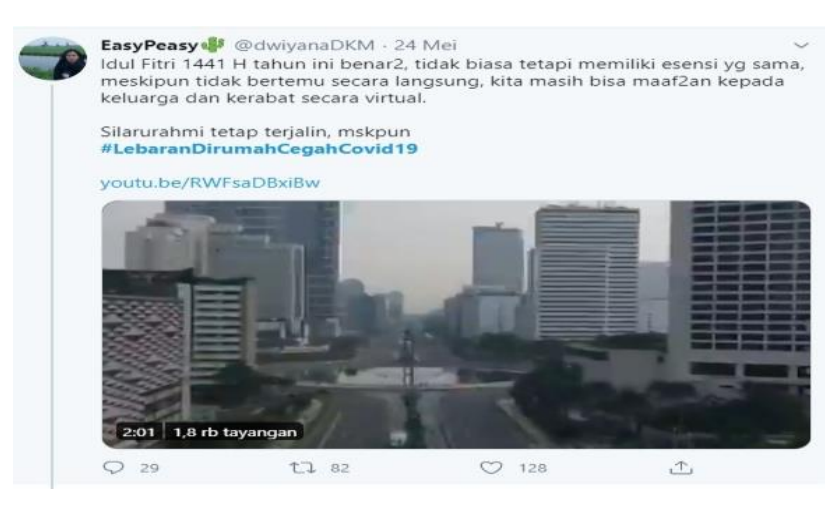




\section{Gambar 17:}

Cuitan akun@dwiyanaDKM dengan tagar \#LebaranDirumahCegahCovid19 mendapat like sebanyak 128, retweet 82, dan reply 29

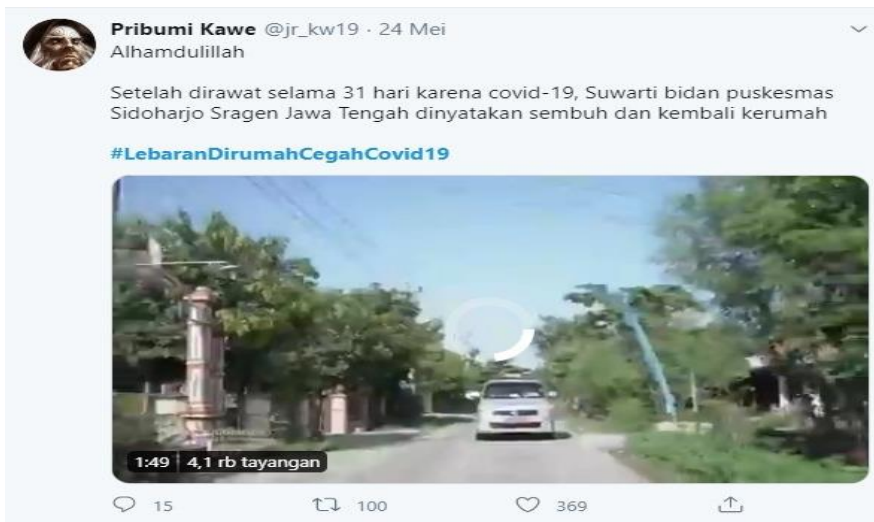

Gambar 18:

Cuitan akun@jr_kw19 dengan menggunakan tagar \#LebaranDirumahCegahCovid19 mendapat like sebanyak 369, retweet 100, dan reply 15

\section{7. \#ImunKuatCovidMinggat}

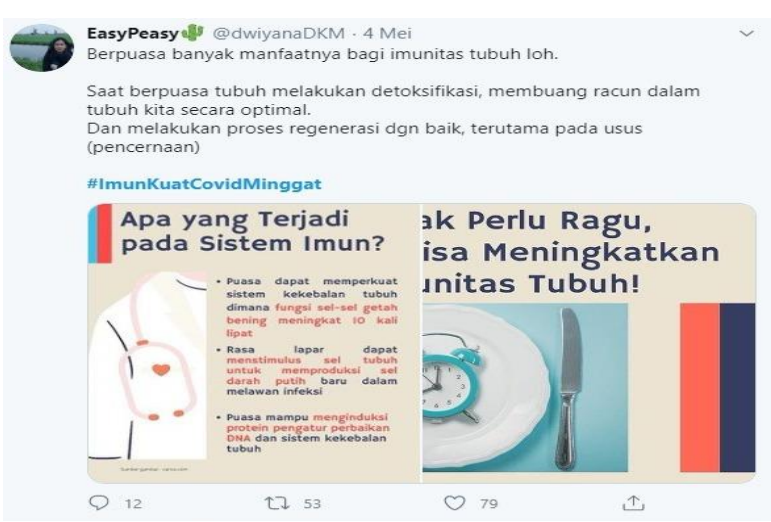

Gambar 19

Cuitan yang dilakukan oleh akun @ dwiyanaDKM dengan menggunakan tagar \#ImunKuatCovidMinggat mendapat like sebanyak 79, retweet 53, dan reply 12 


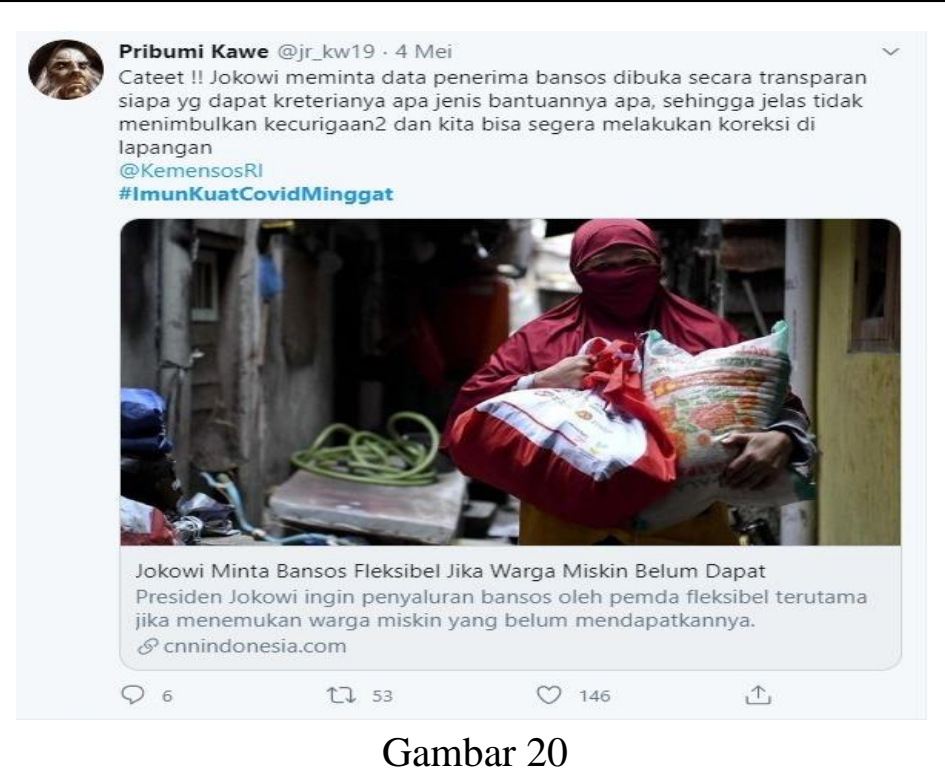

Cuitan akun@jr_kw19 dengan menggunakan tagar \#ImunKuatCovidMinggat mendapat like sebanyak 146, retweet 53, dan reply 6

Setelah menganalisa beberapa cuitan yang dilakukan oleh buzzer diatas, maka ketiga konsep yang dipakai menjawab masalah dalam penelitian ini. Orkestrasi merujuk kepada aktivitas di media sosial yang bertujuan untuk membuat alunan narasi menjadi enak dibaca dan memantik minat banyak netizen untuk ikut terlibat dalam ruang tersebut. Buzzer yang merupakan individu, sekelompok orang, ataupun akun yang memiliki kemampuan dalam bentuk orkestrasi sebuah pesan, menyebarkannya hingga menarik perbincangan oleh khalayak ramai, dan mengamplifikasi pesan tersebut hingga terbangunnya percakapan di media sosial dengan tujuan dan motif tertentu. Konsep terakhir microblogging dalam hal ini Twitter sebagai sebuah bentuk komunikasi baru yang memberikan fitur bagi pengguna untuk dapat menggambarkan status mereka saat ini dalam posting singkat atau pesen pendek sebagai ciri khasnya. Ketiga konsep ini menjawab tujuan penelitian dan menunjukkan bahwa orkestrasi itu penting untuk dilakukan sebagai bagian dari pola komunikasi yang berubah. Efek yang ditimbulkan bisa terlihat dengan banyaknya interaksi oleh followers akun dari buzzer tersebut melalui fitur like, retweet, dan reply. Pesan yang ingin dilakukan oleh aktor komunikasi bisa tersampaikan dengan baik kepada netizen yang berinteraksi dan melihat cuitan dari ketiga akun buzzer.

Orkestrasi yang dilakukan oleh buzzer terkait covid-19 tergambar dengan jelas melalui hestek atau tagar yang terus berganti setiap harinya sesuai list yang telah di observasi pada tabel diatas. Angle yang berbeda setiap harinya walaupun dalam muara isu dan tema yang sama adalah bagian dari upaya akun buzzer untuk memperkaya informasi dan makna dari kampanye agar bisa diterima dengan mudah oleh followersnya masing-masing dari setiap akun tersebut.

Disamping itu, ketiga akun buzzer juga dalam melakukan orkestrasi berhasil menunjukkan konsistensi dalam memainkan isu yang berbeda setiap hari sehingga viralitas yang didapat juga beragam. Kampanye yang dilakukan dalam penanganan virus covid-19 secara simultan juga dilakukan. Dengan jumlah follower yang tinggi juga mempengaruhi 
penyebaran dan kepercayaan netizen terhadap akun tersebut. Hal itu bisa terlihat dari jumlah reach dan impression dari setiap cuitan ketiga akun buzzer tersebut. Seperti diketahui, era industri 4.0 menyebabkan perkembangan media sosial yang sangat masif memunculkan fenomena sosial tersendiri yang disebut dengan cyberculture (Bell, 2001). Hal itu memungkinkan interaksi manusia dengan manusia lainnya dalam aspek komunikasi visual. Dalam dunia cyberspace terdapat ruang bebas bagi individu yang memiliki kecanggihan teknologi untuk melakukan apapun di media sosial.

Konten yang beragam, seperti meme, video, foto dan narasi yang baik sangat dibutuhkan oleh seorang buzzer agar isu yang digerakkan tidak monoton, menrik untuk dibaca, dan bisa disebarluaskan ulang oleh orang lain. Dari ketiga akun buzzer yang diteliti, akun@ChusnulChotimah dan@jr_kw19 memiliki pengaruh yang cukup tinggi karena memliki followers diatas 50 ribu. Sedangkan pesan yang efektif secara rata-rata dimiliki oleh akun@ChusnulChotimah dan @dwiyanaDKM yang terlihat dari banyaknya reply dan retweet dari setiap postingan yang dilakukan.

\section{PENUTUP}

Buzzer menjadi identitas baru dalam memaknai demokrasi di Indonesia. Keberadaanya dibutuhkan oleh banyak pihak sebagai pihak ketiga dalam menyampaikan informasi. Kepercayaan netizen di dunia maya terhadap sebuah akun berbanding lurus dengan dukungan yang diberikan oleh netizen kepada isu yang di orkestrasi. Hubungan timbal balik ini menjadi sebuah keunikan tersendiri dalam kampanye yang terjadi di media sosial. Hal ini tentunya tidak ditemui jika dilakukan dalam bentuk pertemuan dan interaksi langsung.

Kampanye oleh buzzer di media sosial microblogging Twitter merupakan wujud nyata dari bergesernya pola komunikasi masyarakat dalam era industri 4.0. Aktor-aktor komunikasi berperan penting dalam menyampaikan informasi dan membentuk opini publik. Salah satu aktor komunikasi tersebut adalah buzzer yang eksistensinya makin diakui dalam revolusi komunikasi. Setiap kampanye yang dilakukan terhadap sebuah isu memerlukan orkestrasi yang disusun dengan baik oleh buzzer-buzzer di Twitter agar kampanye tersebut bisa tepat sasaran.

Efek yang ditimbulkan dari orkestrasi bisa terlihat dengan banyaknya interaksi oleh followers akun dari buzzer tersebut melalui fitur like, retweet, dan reply. Pesan yang ingin dilakukan oleh aktor komunikasi bisa tersampaikan dengan baik kepada netizen yang berinteraksi dan melihat cuitan dari ketiga akun buzzer. Penelitian ini sukses dengan cermat mengungkap orkestrasi yang dilakukan oleh buzzer terkait covid-19 tergambar dengan jelas melalui hestek atau tagar yang terus berganti setiap harinya sesuai list yang telah di observasi pada tabel diatas. Konsistensi ketiga akun buzzer dalam penelitian ini juga terbukti dengan isu yang berbeda dan mendapatkan penyebaran cukup tinggi dari setiap cuitan. Akun @ChusnulChotimah menjadi akun yang paling tinggi untuk penyebaran dan retweet, diikuti oleh akun@dwiyanaDKM, dan terakhir@jr_kw19.

Permasalahan yang muncul akibat pandemi global virus covid-19 merupakan salah satu isu yang menjadi perhatian serius oleh banyak pihak tak terkecuali oleh buzzer di media 
sosial. Maka penelitian ini mengungkap orkestrasi yang dilakukan di twitter melalui cuitan beserta tagar yang terhimpun dalam satu bulan. Penelitian ini juga menjawab kekurangan dari penelitian sebelumnya yang fokus meneliti buzzer dari segi kampanye politik atau pemasaran. Isu kesehatan dan nyawa manusia karena wabah global adalah hal baru bagi kerja-kerja buzzer. Kebaruan ini menjadi rekomendasi bagi penelitian lainnya dalam ruang lingkup buzzer dan orkestrasi terkait krisis dan wabah yang terjadi secara mendadak. Sehingga, penelitian tentang buzzer tidak berkutat hanya pada tataran politik dan brand, namun juga merambah isu lain yang lebih luas seperti pandemi saat ini yang banyak berkaitan dengan ekonomi dan kesehatan.

Kekurangan dari peneltiian ini adalah tidak terdapat wawancara mendalam bersama ketiga pemilik akun yang diteliti dikarenakan aturan Pembatasan Sosial Berskala Besar yang sedang dijalankan di Jakarta. Kekurangan tersebut ditutupi dengan observasi mendalam terhadap ketiga akun buzzer mulai dari profil, cuitan, dan tagar yang di orkestrasi untuk menjawab permasalahan dalam penelitian ini.

\section{REFERENSI}

Abugaza, Anwar. (2013). Social media politica: Gerak massa tanpa lembaga. Tangerang: PT Tali Writing \& Publishing House.

Arbie, Rivani. (2013). Twitter is money. Jakarta: Mediakita

Bell, D. (2001). An Introduction to Cybercultures. New York: Routledge

Camil, R., Attamimi, N. H., \& Esti, K. (2017). Dibalik fenomena buzzer: Memahami lanskap industri dan pengaruh buzzer di Indonesia. Centre for Innovation Policy and Governance, 1-28.

Conover, MD et al. (2011) Political Polarization on Twitter. Proceedings of the Fift $h$ International AAAI Conference on Weblogs and Social media 2011.

Data Survei Asosiasi Penyelenggara Jasa Internet Indonesia (APJII). (2017). Infografis: Penetrasi \& perilaku pengguna internet Indonesia. Diunduh tanggal 21 Maret 2018. Diakses dari https://apjii.or.id/content/read/39/342/Hasil-Survei-Penetrasi-danPerilaku-Pengguna-Internet-Indonesia-2017

Felicia, Riris Loisa. (2018). Peran buzzer politik dalam aktivitas kampanye di media sosial twitter. Jurnal Koneksi Vol. 2, No. 2, Desember 2018, Hal 352-359

Graham, M. W. (2014). Government communication in the digital age : Social media's effect on local government public relations. Public Relations Inquiry, 3(3), 361-376. https://doi.org/10.1177/2046147X1 4545371

Java, A., Song, X., Finin, T. \& Tseng, B. (2007). Why we Twitter: Understanding microblogging usage and communities. Proceedings of the 9th WebKDD 2007 workshop on Web mining and social network analysis (pp. 56-65). New York, NY: Association for Computing Machiner

Juditha, Christiany. (2017). Buzzer di media sosial pada pilkada dan pemilu Indonesia. Prosiding Seminar Nasional Komunikasi dan Informatika \#3 Tahun 2019: 199-212

Juliadi, Rismi. (2017). The Construction of Buzzer Identity on Social Media (A Descriptive Study of Buzzer Identity in Twitter) Conference: $3^{\text {rd }}$ International Conference on 
Transformation in Communication (ICoTiC 2017), At Bandung, Indonesia. Diakses dari website: https://www.researchgate.net/publication/330101637_The_Construction_of_Buzzer_ Identity_on_Social_Media_A_Descriptive_Study_of_Buzze r_Identity_in_Twitter, 21 Maret 2019.

Karuayawanto, H., Y. (2018). Bentuk lagu dan ambitus nada pada orkestrasi mars UNESA. VIRTUOSO Jurnal Pengkajian Dan Penciptaan Musik, Vol. 1 No. 1

Kemp, S. (2018). Digital in 2018: World internet users pass the billion mark. Available from: https://wearesocial.com/blog/2018/0 1/global-digital-report-2018.

Kompas.com. (2019). "Separuh penduduk indonesia sudah "melek" media sosial", https://tekno.kompas.com/read/2019/02/04/19140037/separuh-penduduk-indonesiasudah-melek-media-sosial. Diakses 21 Maret 2019

Kotler, Philip \& Gary Armstrong. (2012). Prinsip prinsip pemasaran. Edisi13. Jilid 1. Jakarta: Erlangga.

Loisa, R., \& Setyanto, Y. (2012). Mencari bentuk kampanye politik khas Indonesia: Pencitraan berbasis dimensi budaya (online). Diakses dari website: http:// komunikasi. unsoed.ac.id/ sites/default/files/52.RIRISLOISA_tarumanagara.pdf>, pada 21 Maret 2019.

Meranti, \& Irwansyah. (2018). Kajian humas digital: Transformasi dan kontribusi Industri 4.0 pada Stratejik Kehumasan. Jurnal Teknologi Informasi dan Komunikasi, 7(1), 27-36. https://doi.org/10.2527/jas20125761

Moleong, Lexy J. 2004. Metode penelitan kualitatif. Bandung: Rosdakarya

Murthy, D. (2018). Twitter. United Kingdom: Polity Press

Nakano, D., \& Muniz Jr, J. (2018). Writing the literature review for empirical papers. Producation, 28, e20170086. https://doi.org/10.1590/0103-6513.20170086

Neuman, W. L. (2014). Social Research methods: Qualitative and quantitative approaches. Pearson Education Limited (Vol. 7). https://doi.org/10.2307/3211488

Pfefferman, N., Minshall, T., \& Mortara, L. (2013). Strategy and Communication for Innovation (2nd ed.). Springer. https://doi.org/10.1007/978-3-64241479-4

Ridley, D. (2012). The literature review a stepby-step guide for students (2nd Edition). London: Sage Pub.

Rohandi, M. M. A. (2016). Effective marketing communicaton : word of mouth. Jurnal Manajemen dan Bisnis, XIII (1), 1-14.

Safko, L. (2010). The social media bible: The social media bible: tactics, tools, and strategies for bussines success. Second Edition. New Jersey: John Wiley \& Sons

Sujarweni, A. W. (2014). Metodologi penelitian. Yogyakarta: Pusataka Baru.

Turpin, Dominique. (2008). Buzz marketing. Switzeland: IMD (http://www.imd.org/research/challenges/upload/TC096-08_buzz_marketing.pdf)

Veil, S. R., Reno, J., Freihaut, R., \& Oldham, J. (2015). Online activists vs. Kraft foods: A case of social media hijacking. Public Relations Review, 41(1), 103-108. https://doi.org/10.1016/j.pubrev.2014.11.017

Wahyuningtyas, D. (2017). Buzzer twitter pada publikasi organisasi pemerintah: studi isi asosiasi topik tweet, tujuan tweet, desain penyusunan pesan, dan feedback akun 
buzzer twitter kementerian keuangan. Retrieved from https://eprints.uns.ac.id/id/eprint/36 425

Xiao, Y., \& Watson, M. (2017). Guidance on Conducting a Systematic Literature Review. Journal of Planning Education and Research, 1-20. https://doi.org/10.1177/0739456X1 77239

Zed, Mestika. (2008). Metode Penelitian Kepustakaan. Jakarta: Buku Obor. 